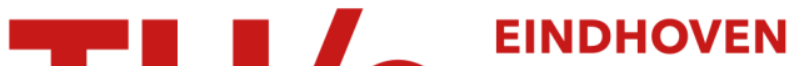 UNIVERSITY OF TECHNOLOGY
}

\section{Finite element analysis of fibrous tissue morphogenesis : a study of the osteogenic index with a biphasic approach}

\section{Citation for published version (APA):}

Prendergast, P. J., \& Huiskes, H. W. J. (1996). Finite element analysis of fibrous tissue morphogenesis : a study of the osteogenic index with a biphasic approach. Mechanics of Composite Materials, 32(2), 144-150. https://doi.org/10.1007/BF02254782

DOI:

10.1007/BF02254782

Document status and date:

Published: 01/01/1996

\section{Document Version:}

Publisher's PDF, also known as Version of Record (includes final page, issue and volume numbers)

\section{Please check the document version of this publication:}

- A submitted manuscript is the version of the article upon submission and before peer-review. There can be important differences between the submitted version and the official published version of record. People interested in the research are advised to contact the author for the final version of the publication, or visit the $\mathrm{DOI}$ to the publisher's website.

- The final author version and the galley proof are versions of the publication after peer review.

- The final published version features the final layout of the paper including the volume, issue and page numbers.

Link to publication

\section{General rights}

Copyright and moral rights for the publications made accessible in the public portal are retained by the authors and/or other copyright owners and it is a condition of accessing publications that users recognise and abide by the legal requirements associated with these rights.

- Users may download and print one copy of any publication from the public portal for the purpose of private study or research.

- You may not further distribute the material or use it for any profit-making activity or commercial gain

- You may freely distribute the URL identifying the publication in the public portal.

If the publication is distributed under the terms of Article 25fa of the Dutch Copyright Act, indicated by the "Taverne" license above, please follow below link for the End User Agreement:

www.tue.nl/taverne

Take down policy

If you believe that this document breaches copyright please contact us at:

openaccess@tue.nl

providing details and we will investigate your claim. 


\title{
FINITE ELEMENT ANALYSIS OF FIBROUS TISSUE MORPHOGENESIS - A STUDY OF THE OSTEOGENIC INDEX WITH A BIPHASIC APPROACH*
}

\author{
P. J. Prendergast and R. Huiskes
}

The development of tissues in the skeleton is a complex process beginning with mesenchymal cells in a blastema and finishing with some "equilibrium" tissue suited to the mechanical function required for the particular skeletal part. The process involves differentiation of the pluripotent mesenchymal cells into those that form the particular equilibrium tissue, e.g., chondrocytes for cartilage or osteoblasts for bone. Several philosophers in the previous century have hypothesized that the process is not just genomic, but that mechanical factors play a part in determining the pathway which is followed [1]. Nonetheless, very little is yet known about the mechanical events that underlie the tissue formation process.

Based on an idea proposed by the German orthopaedic surgeon F. Pauwels [2] concerning the relative influence of hydrostatic and shear stresses, it has been proposed by Carter [3] that the tendency for fibrous connective tissue, cartilage, or bone to be formed could be captured by an osteogenic index

$$
O I=\sum_{i=1}^{c} n_{i}\left(S_{i}+k D_{i}\right)
$$

where $S$ and $D$ denote the cyclic octahedral shear stress and hydrostatic stress respectively, $k$ is a constant weight factor, $n_{i}$ is the number of loading cycles of a particular loading condition, and $\mathrm{c}$ is the number of such different loading conditions. Representing the tissue as an elastic and isotropic solid, finite element models have been developed to analyze the morphogenetic behavior of tissues [3-5]. It has been suggested that this kind of modeling approach is able to describe features of fracture repair and chondrogenesis [3], and ligament [4] and tendon [5] tissue phenotype.

Despite the convenience of the elastic approach, it is clear that the tissue itself is a material containing both solid and fluid constituents (called a biphasic material). The solid phase is mainly a certain type of collagen mixed with proteoglycans, whereas the fluid phase consists of blood and interstitial fluid. Since the cells that undergo differentiation (mesenchymal cells) are contained in the fluid until such time as they become precursors for tissue forming cells [6], it seems worthwhile to ask whether or not a model derived from the fundamental biphasic nature of the tissue would lead us toward a better understanding of the phenomenon of tissue development.

To investigate this idea, we generated a finite element model of peri-prosthetic tissue formation observed in an animal experiment, using both elastic and biphasic [7] finite element analyses. The animal experiments analyzed in this investigation have been reported in the doctoral dissertation of Søballe [8]. The osteogenic index was calculated in the gap between implant and bone, using both linear elastic and biphasic tissue models. Since the fluid phase moves relative to the solid, it is possible that the osteogenic stimulus might arise as a result of fluid motion. To investigate this, the velocity of fluid relative to solid phase was calculated. Results are compared to the histological results reported by Seballe [8]. Finally, some discussion of how a morphogenic stimulus might really arise is given.

\section{Methods}

Soballe [8] implanted a micromotion device into the condyles of dogs (Fig. 1). The implant was attached to a piston that moved axially under the load of weight bearing. Axial movement was limited to either $150 \mu \mathrm{m}$ in one set of experiments or $500 \mu \mathrm{m}$ in another. The spring ensured that the implant returned to the lower position when the weight-bearing load was

*Presented at the Ninth International Conference on the Mechanics of Composite Materials, Riga, October, 1995.

Biomechanics Section. Institute of Orthopaedics, University of Nijmegen. Postbus $9101,6500 \mathrm{HB}$ Nijmegen, The Netherlands. Published in Mekhanika Kompozitnykh Materialov, Vol. 32, No. 2, pp. 209-218, March-April. 1996. Original article submitted April 28, 1995. 


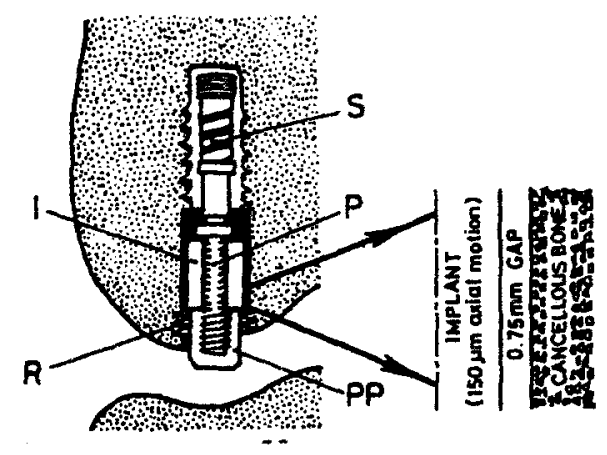

Fig. 1. From Søballe [8], the micromotion device with implant (I) screwed onto piston (P). The spring (S) is contained in a hollow screw (HS). A polyethylene plug (PP) extends below the bone surface to engage the lower condyle on loading.

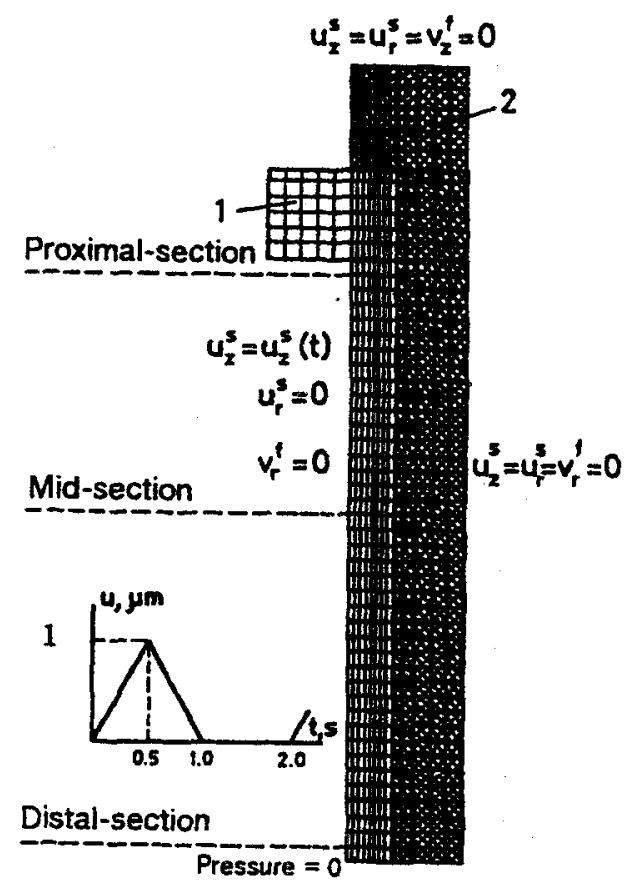

Fig. 2. Finite element model of the gap tissue and bone tissue with restraints indicated for the biphasic tissue representation. The inset shows the loading mode. The labels "proximal," "middle," and "distal" refer to the positions where the osteogenic index is reported.

removed. The effects of these levels of micromotion were compared with those in animals where all motion of the implant was restrained. The effect of different implant coatings was also investigated but that effect will not be considered in this paper. A gap of $750 \mu \mathrm{m}$ was retained around the implant within which tissue formed. Depending on the extent of the micromotion and the time after implantation. various amounts of fibrous connective tissue, fibrocartilage or bone formed in the peri-implant gap.

An axisymmetric finite element model of the gap tissue and surrounding cancellous bone was developed to analyze the biomechanical behavior of the environment surrounding the implant. Two kinds of constitutive behavior for the tissues were considered: 


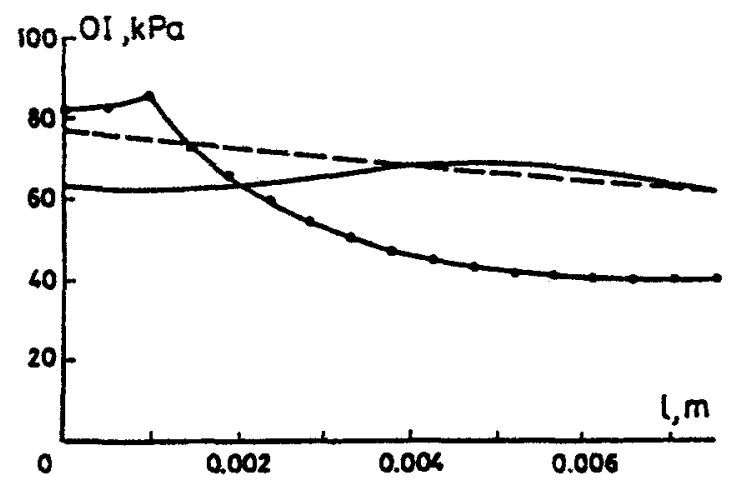

Fig. 3. Linear elastic tissue model: Osteogenic index in the gap tissue and a graph of osteogenic index as a function of radial distance from the implant surface, for the proximal, middle, and distal gap sections.

(i) an isotropic linear elastic representation, where Young's modulus and Poisson's ratio were approximated by I $\mathrm{MPa}$ and 0.1667 for soft gap tissue and $100 \mathrm{MPa}$ and 0.3 for cancellous bone.

(ii) a biphasic representation, where gap tissue and cancellous bone were considered to contain fluid. The permeability of the cancellous bone was taken to be $3.71 \times 10^{-13} \mathrm{~m} / 4 / \mathrm{N} \cdot \sec$ [9]. The permeability of the gap tissue has not been measured. Armstrong and Mow [10] determined the permeability of cartilage as a funcrion of water content. According to their results, $2.0 \times 10^{-15} \mathrm{~m}^{4} / \mathrm{N} \cdot \mathrm{sec}$ is approximately a permeability corresponding to an equilibrium modulus of $1 \mathrm{MPa}$.

The displacements in the model were restrained at the cancellous border, and prescribed to move $150 \mu \mathrm{m}$ at the implant/gap interface (Fig. 2). For the biphasic model, a nonlinear finite element solution was obtained with a time step of $0.02 \mathrm{sec}$ using 25 iterations to reach the maximum deflection of $150 \mu \mathrm{m}$, and the same to return to the zero displacement position; thereafter $1 \mathrm{sec}$ of no loading was simulated using a $0.1 \mathrm{sec}$ time step. For the biphasic model, considerable variation in the solution occurs depending on the pressure and velocity prescriptions at the boundary. In the eventual analysis, the fluid velocity was set to zero at the boundary of the cancellous bone in the model, and the pressure was prescribed to be zero at the distal end.

Since the tissue in the peri-implant gap is undergoing tissue differentiation, there is an interchange of mass between the fluid phase and the solid phase (the solid phase consists of collagenous constituents and, for bone, hydroxyapatite constituents). In this case the balance laws for a biphasic mixture (see [7]) have to include terms relating to the reactive nature of the mixture [11]. For the mixture as a whole, the balance equations for the mass requires

$$
c^{x}+c^{s}=0
$$

where $c$ denotes the rate of mass transfer per unit volume $\left[\mathrm{kg} \cdot \mathrm{s}^{-1} / \mathrm{m}^{3}\right]$ and the superscripts denote solid and fluid respectively. In addition to the Stokes drag (denoted $\pi$ ), the balance of linear momentum must include "reactivity" terms, i.e.,

$$
\pi^{2}+\pi^{\prime}+\rho^{\prime} c^{2} v^{\prime}+\rho^{\prime} c^{\prime} v^{\prime}=0
$$

where $\rho$ denotes density and $\mathbf{v}$ denotes the velocity. For a homogeneous medium,

$$
\pi^{\prime}=-\pi^{s}=K\left(v^{p}-v^{\prime}\right)
$$

where $K$ is the diffusive drag coefficient related to the permeability (denoted $k$ ) as $k=\varphi_{f}^{2} / K$, where $\varphi_{f}$ is the volume fraction of fluid [12]. The terms in Eq. (3) have units of momentum per unit volume per unit time. Finally, the first law of thermodynamics gives

$$
r^{\prime}+r^{\prime}+c^{\prime}\left(\varepsilon^{s}+\frac{1}{2} v^{s} \cdot v^{s}\right)+c^{\prime}\left(\varepsilon^{\prime}+\frac{1}{2} v^{\prime} \cdot v^{\prime}\right)+\pi^{\prime} \cdot v^{s}+\pi^{\prime} \cdot v^{\prime}=0
$$

where $\mathrm{r}$ denotes the heat production of the constituents and $\varepsilon$ denotes the specific internal energy. Note that the bracketed terms of Eq. (4) contain both the internal energy and the kinetic energy of the transferred mass, and therefore assume that the new mass is energetically indistinguishable from the mass already present at that position in that phase. 


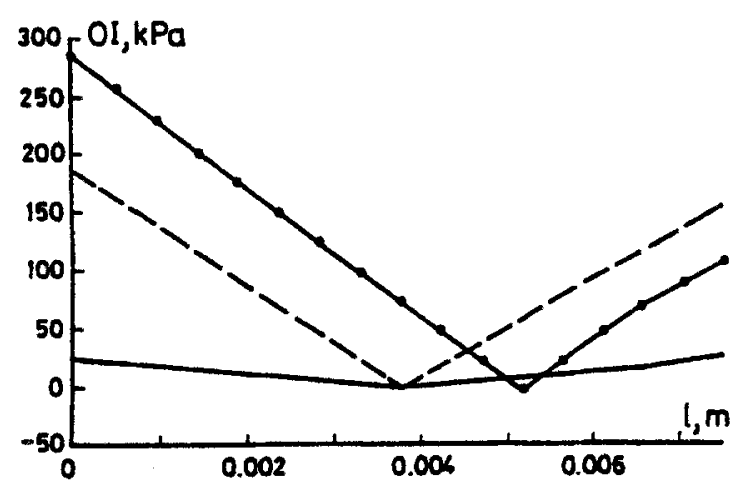

Fig. 4. Biphasic tissue model: Osteogenic index in the gap tissue and a graph of osteogenic index as a function of radial distance, for $0.25 \mathrm{sec}, 0.5 \mathrm{sec}$, and $0.75 \mathrm{sec}$ in the loading cycle (mid-section only reported).

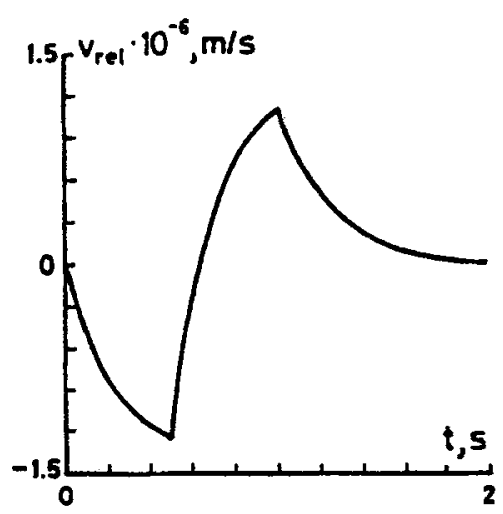

Fig. 5. Fluid velocity vs. time for a sampling position midway down the implant and halfway across the gap.

The second law of thermodynamics for a reacting continuum has been considered by Truesdell [13] and by Kelly [11]. Entropy flows between constituents are postulated to account for the self-organizational events in the tissue [14]. Despite the evident importance of this hypothesis, it will not be discussed in this paper.

\section{Results}

The osteogenic index [defined in Eq. (1) above] was calculated in the gap tissue for both linear elastic and biphasic material descriptions. For the biphasic material description it refers to the relationship between the deviatoric and hydrostatic stresses in the solid phase only, so it is not an apparent level quantity. Considering the linear elastic representation, the osteogenic index was found to decrease across the gap (see Fig. 3), and the decrease was linear at the mid-section of the implant. The values calculated in this sndy are numerically similar to those found by Carter [3] for a fracture callus. With the biphasic representation, the variation was completely different because the solid tissue was deformed substantially by the drag forces generated by fluid flow. Specifically, fluid flow occurs opposite to the direction of implant motion, due to the pumping action of the implant. The result is tissue deformation opposite to the direction of implant motion, and exudation of fluid from the distal end of the gap. Therefore, whilst the tissue attached to the implant moved the full $150 \mu \mathrm{m}$, the tissue further into the gap was forced (due to fluid drag) to displace in the opposite direction. This explains the different osteogenic index values calculated for the biphasic tissue representation. Furthermore, due to the nonlinear nature of the biphasic effect, the osteogenic index varied during the load cycle (Fig. 4). 
The velocity of the fluid was calculated to ascertain whether or not the momentum transfer due to the change in velocity is large relative to the momentum transfer due to the change in mass. The velocity of the fluid relative to the solid in the axial direction reaches a maximum value of approximately $1.25 \mu \mathrm{msec}^{-1}$ (see Fig. 5). Therefore, an estimate of the momentum supply to the fluid phase is given by

$$
\pi^{\prime}=K\left(\mathrm{v}^{\prime}-\mathrm{v}^{3}\right) \approx \frac{1}{2.0 \cdot 10^{-13}} \cdot 1.25 \cdot 10^{-1}=6.25 \cdot 10^{4} \mathrm{~kg} \cdot \mathrm{m}^{-2} \cdot \mathrm{s}^{-2}
$$

An estimate of the momentum supply to the mixture due to reactivities [i.e., the third and fourth components of Eq. (3)] can be obtained by considering that, in this particular experiment, fibrous encapsulation by fibrous connective tissue was observed after four weeks (i.e., approximately $2.4 \times 10^{6} \mathrm{sec}$ ) when the implant was under no micromotion. Assuming a linear rate of mass formation and taking the density as $1000 \mathrm{~kg} \cdot \mathrm{m}^{-3}$, and, from Eq. (2) $c=c^{\mathrm{s}}=-\mathrm{c}^{\mathrm{f}}$, we can approximate the sum of the reactivity terms as

$$
\rho c\left(v^{\prime}-v^{\prime}\right) \approx 1000 /\left(2.4 \cdot 10^{4}\right) \cdot 1.25 \cdot 10^{-6} \approx 5.2 \cdot 10^{-10} \mathrm{~kg} \cdot \mathrm{m}^{-2} \cdot \mathrm{s}^{-2}
$$

In this way, it is shown that the terms due to reactivity are much smaller than those due to mechanical momentum transfer (Stokes drag) and can therefore, as a first approximation, be neglected in this analysis. We return to this important point in the discussion.

\section{Discussion}

Before discussing the results, we must acknowledge that any mathematical model of morphogenesis must be riddled with simplifications because of the extreme complexity of the morphogenetic process. The benefits of a biphasic material approach over an elastic material approach might seem obvious at first since the tissue contains both collagenous solids and blood and water fluids. However, the elastic osteogenic index [3] and the accompanying arguments about cell shape [5, 15] have allowed quantification of the role of mechanical factors in morphogenesis and skeletal regeneration. The present results additionally show that the osteogenic index might not be linked in any direct way to the forces acting on mesenchymal cells, or any precursor cells, that are transported in the fluid. Even for cells lodged in the solid phase of the fibrous tissue, such as chondrocytes or fibrocytes [16], the flow of the fluid can significantly alter the deformation of the solid due to Stokes drag forces - though this result must be taken tentatively given that the permeability of the peri-implant fibrous tissue has not yet been measured. Specific analysis of the fracture callus and embryogenic mouse limbs [17] shows that this conclusion might also be extrapolated to those biomechanical systems.

To what extent does the biphasic finite element model developed in this paper represent the actual structural behavior of the implant/gap/cancellous bone system? The geometry is well defined, but the boundary conditions and material properties can only be approximated at this stage. We have assumed that no fluid flow occurs into the volume under analysis, i.e., that sufficiently far into the cancellous bone, there is no effect of the implant. This assumption seems to be a good one if the cancellous bone is clogged with marrow at some distance away from the cancellous bone/fibrous tissue junction. However, if the gap tissue vascularises, the system will no longer be close with respect to mass. Angeogenis may occur, and arteries and veins will traverse this boundary creating fluid flows into the system. Regarding material properties, the gap tissue has been analyzed histologically, and found to be either fibrous connective tissue or fibrocartilage or a mixture of the two [8]. The permeability of this tissue has not been measured, however, and this is a serious limitation to the present analysis. For the moment, we rely on the values measured for cartilage as a function of Young's modulus and water content [10].

The different osteogenic index in the biphasic material model arises because the deformation of the tissue is not linear across the gap. The result is that the maximum shear strains occur near the implant surface and the bone surface causing the osteogenic index to be large there. and to have a minimum near the center of the gap. It is noteworthy that tissue development begins on these surfaces in reality (see Saballe [8]). On the other hand, the elastic material model obviously predicts constant decrease in shear across the gap resulting in a similar $c$ index. Thus, the osteogenic index prediction seems to work best when the tissue is modeled as a biphasic material.

The biphasic approach to tissue modeling presented in this paper is analogous to the bone remodeling approach which models the tissue as a control system of a solid and a fluid "perfusant" (Cowin and Hegedus [18]). In bone remodeling, it is 
assumed that the forces of interaction between the components of the tissue are small compared with the forces in the solid component. The tissue morphogenesis analysis presented in this paper differs from the bone remodeling analysis since. for example, (i) the fluid/soild interaction has significant importance and is accounted for; and (ii) the whole system is considered closed with respect to mass, i.e., any new collagenous tissue generated must come from the materials present in the fluid and precursor tissues whereas the mass balance of adaptive elasticity theory [18] does not account for the "prefusant." No momentum or energy crosses the boundary except that introduced mechanically due to the motion of the implant. Since the time required for fibrous encapsulation of the peri-implant gap was determined experimentally, we have been able to approximate the fluid-to-solid mass exchange rate and thus calculate values for the last two terms of Eq. (3). It is seen that, when the rate of tissue formation is assumed linear, the momentum transfer due to reactivity is negligible. Further discussion is needed on this point because, in truth, the tissue formation rate is unlikely to be linear. Instead, morphogenesis most likely proceeds as a series of "bursts" or "local explosions" where the mass transfer rate between phases is, for some brief period of time, very high. If this were to be true, then the reactivity terms of Eq. (3) might be an important determinant of the partial stresses of the solid and fluid phases. It is possible that these "explosions" might originate from mechanical energy released from microdamage of the collagenous network. This could initiate a remodeling response in a process of attuning the tissue to its mechanical environment [19].

The work presented here assumes a technological significance for the design of load bearing implants. Very complex stress patterns occur at the junctions between implant and bone, and these complex stresses are responsible for a host of failure interactions [20]. In particular, fibrous tissue formation occurs on the bone/implant interface of intramedullary fixated implants. The rational design of these load bearing structures will eventually require a method for analysis and prediction of fibrous tissue formation. The present approach is offered as a promising basis for such analyses.

\section{Acknowledgements}

The European Commission (Directorate-General for Science and Technology) provided the financial support under the grant "The structural modeling of bone/implant interfaces." Willem D. van Driel, M.S., gave some useful comments on this paper.

\section{REFERENCES}

1. H. Roesler, "The history of some fundamental concepts in bone biomechanics," J. Biomech., 20, Nos. 11/12, 10251034 (1987).

2. F. Pauwels, "Grundriß einer Biomechanik der Frakturheilung," in: 34th Kongress der Deutschen Orthopädischen Gesellschaft, Ferdinand Enke Verlag, Stuttgart (1940), pp. 62-108. Translated into the English by P. Manquet and R. Furlong, "Biomechanics of fracture healing," in: Biomechanics of the Locomotor Apparatus, Springer, Berlin (1986), pp. 106-137.

3. D. R. Carter, "Mechanical loading history and skeletal biology," J. Biomech., 20, Nos. 11/12, 1095-1109 (1987).

4. J. R. Matyas, M. G. Anton, N. G. Shrive, and C. B. Frank, "Stress governs tissue phenotype at the femoral insertion of the rabbit MCL," J. Biomech., 28, No. 2, 147-157 (1995).

5. N. J. Giori, G. S. Beaupré, and D. R. Carter, "Cellular shape and pressure may mediate mechanical control of tissue composition in tendons," J. Orthopaedic Res., 11, No. 4, $581-591$ (1993).

6. A. I. Kaplan. "Mesenchymal stem cells," J. Orthopaedic Res., 9, No. 5, $641-650$ (1991).

7. V. C. Mow, S. C. Kuei, W. M. Lai, and C. G. Armstrong, "Biphasic creep and stress relaxation of articular cartilage: theory and experiments," J. Biomech. Eng., 102, No. 1. 73-84 (1980).

8. K. Søballe, "Hydroxyapatite ceramic coating for bone implant fixation. Mechanical and histological studies in dogs," Acta Orthopaedica Scand.. 64, Supplementum No. 255 (1993).

9. J. A. Ochoa and B. M. Hillberry, "Permeability of bovine cancellous bone," Transactions of the 38th Annual Meeting. Orthopaedic, Research Society (1992), p. 162.

10. C. G. Armstrong and V. C. Mow, "Variations in the intrinsic mechanical properties of human articular cartilage with age, degeneration and water content," J. Bone Joint Surgery, 64A, No. 1, 88-94 (1982). 
11. P. D. Kelly, "A reacting continuum," Inter. J. Eng. Sci., 2, No. 2, 129-153 (1960).

12. W. M. Lai and V. C. Mow. "Drag induced compression of articular cartilage during a permeation experiment," Biorheology, 17, Nos. 1/2, 111-123 (1980).

13. C. A. Truesdell, "Sulle basi della termodinamica delle miscele." Lincei. Rend. (Roma), 75. $381-383$ (1968).

14. G. Nicolis and I. Prigogine, Self-organization in Nonequilibrium Systems. From Dissipative Structures to Order through Fluctuations, John Wiley and Sons. New York (1977).

15. D. R. Carter and N. J. Giori, "Effect of mechanical stress on tissue differentiation in the bony implant bed," in: The Bone-Biomaterial Interface, J. E. Davies (ed.), University of Toronto Press (1991), pp. 367-376.

16. R. Y. Hori and J. L. Lewis, "Mechanical properties of the fibrous tissue found at the bone-cement interface following total joint replacement," J. Biomedical Mater. Res., 16, $911-927$ (1982).

17. W. D. van Driel, R. Huiskes, and E. H. Burger, "The role of interstitial fluid flow in fetal cartilagenous bone tissue mineralization," Irish J. Medical Sci., 165, No. 1. 82 (1996).

18. S. C. Cowin and D. H. Hegedus, "Bone remodelling I. theory of adaptive elasticity," J. Elasticity, 6, No. 3, 313326.

19. P. J. Prendergast and D. Taylor, "Prediction of bone adaptation using damage accumulation," J. Biomechanics, 27. No. 8, 1067-1076 (1994).

20. R. Huiskes and D. Nunamaker, "Local stresses and bone adaptation around orthopaedic implants," Calcified Tissue Int., 36, Supplement 1, 110-117 (1984). 